Article

\title{
Evaluation of the Nitrous Oxide Emission Reduction Potential of an Aerobic Bioreactor Packed with Carbon Fibres for Swine Wastewater Treatment
}

\author{
Takahiro Yamashita ${ }^{1, *}$, Makoto Shiraishi ${ }^{2}$, Hiroshi Yokoyama ${ }^{1}$, Akifumi Ogino ${ }^{1}$, \\ Ryoko Yamamoto-Ikemoto ${ }^{3}$ and Takashi Osada ${ }^{1}$ \\ 1 Animal Waste Management and Environment Division, NARO Institute of Livestock and Grassland Science, \\ Tsukuba, Ibaraki 305-0901, Japan; hiroshiy@affrc.go.jp (H.Y.); aogino@affrc.go.jp (A.O.); \\ osada@affrc.go.jp (T.O.) \\ 2 Research Institute for Livestock Science, Okayama Prefectural Technology Center for Agriculture, Forestry \\ and Fisheries, Misakicho, Okayama 709-3494, Japan; makoto_shiraishi@pref.okayama.lg.jp \\ 3 Institute of Science and Engineering, Kanazawa University, Kanazawa, Ishikawa 920-1192, Japan; \\ rikemoto@se.kanazawa-u.ac.jp \\ * Correspondence: yamatktk@affrc.go.jp; Tel.: +81-29-838-8600
}

Received: 15 February 2019; Accepted: 11 March 2019; Published: 15 March 2019

\begin{abstract}
Nitrous oxide $\left(\mathrm{N}_{2} \mathrm{O}\right)$ is a potent greenhouse gas that is emitted from wastewater treatment plants. To reduce emissions of $\mathrm{N}_{2} \mathrm{O}$ from swine wastewater treatment plants, we constructed an experimental aerobic bioreactor packed with carbon fibres (ca. $1 \mathrm{~m}^{3}$ bioreactor) as an alternative to conventional activated sludge treatment. The $\mathrm{N}_{2} \mathrm{O}$ emission factor for the aerobic bioreactor packed with carbon fibres (CF) was $0.002 \mathrm{~g} \mathrm{~N}_{2} \mathrm{O}-\mathrm{N} / \mathrm{g}$ TN-load and the value for the typical activated sludge (AS) reactor was $0.013 \mathrm{~g} \mathrm{~N}_{2} \mathrm{O}-\mathrm{N} / \mathrm{g}$ TN-load. The $\mathrm{CF}$ treatment method achieved more than $80 \%$ reduction of $\mathrm{N}_{2} \mathrm{O}$ emissions, compared with the AS treatment method. The experimental introduction of a CF carrier into an actual wastewater treatment plant also resulted in a large reduction in $\mathrm{N}_{2} \mathrm{O}$ generation. Specifically, the $\mathrm{N}_{2} \mathrm{O}$ emission factors decreased from 0.040 to $0.005 \mathrm{~g} \mathrm{~N} 2 \mathrm{O}-\mathrm{N} / \mathrm{g}$ TN-load following application of the carrier. This shows that it is possible to reduce $\mathrm{N}_{2} \mathrm{O}$ generation by more than $80 \%$ by using a CF carrier during the operation of an actual wastewater treatment plant. Some bacteria from the phylum Chloroflexi, which are capable of reducing $\mathrm{N}_{2} \mathrm{O}$ emissions, were detected at a higher frequency in the biofilm on the $\mathrm{CF}$ carrier than in the biofilm formed on the AS reactor.
\end{abstract}

Keywords: carbon fibres; denitrification; nitrous oxide emission; swine wastewater

\section{Introduction}

Greenhouse gases, such as carbon dioxide $\left(\mathrm{CO}_{2}\right)$, methane $\left(\mathrm{CH}_{4}\right)$ and nitrous oxide $\left(\mathrm{N}_{2} \mathrm{O}\right)$, are emitted from wastewater treatment plants. These gases enhance the warming of Earth's surface. In particular, $\mathrm{N}_{2} \mathrm{O}$ is a potent greenhouse gas that accounts for $7.9 \%$ of global anthropogenic greenhouse gas emissions; it has an approximately 300-fold stronger effect than $\mathrm{CO}_{2}$ over a 100-year period [1]. $\mathrm{N}_{2} \mathrm{O}$ is produced during biological nitrogen conversions in wastewater treatment plants. Most soluble nitrogen in wastewater exists as ammonium ions $\left(\mathrm{NH}_{4}{ }^{+}\right) \cdot \mathrm{NH}_{4}{ }^{+}$is oxidized to nitrite ions $\left(\mathrm{NO}_{2}{ }^{-}\right)$and nitrate ions $\left(\mathrm{NO}_{3}{ }^{-}\right)$under aerobic conditions and these are reduced to $\mathrm{N}_{2}$ gas under anoxic conditions by microorganisms. During denitrification, unlike nitrification, $\mathrm{N}_{2} \mathrm{O}$ is a regular intermediate. If denitrification occurs completely, $\mathrm{N}_{2} \mathrm{O}$ becomes $\mathrm{N}_{2}$ gas and the release of $\mathrm{N}_{2}$ gas to the atmosphere removes nitrogen from the reaction tank. $\mathrm{N}_{2}$ gas is not a greenhouse gas (GHG); therefore, converting these ions into $\mathrm{N}_{2}$ gas is important. Nitrification and denitrification progress smoothly in 
the environment when conditions encourage the growth of microbes. However, $\mathrm{N}_{2} \mathrm{O}$ emissions often increase when nitrification and denitrification are inhibited by water temperature, dissolved oxygen (DO) concentrations or organic matter concentrations [2,3]. In the conventional wastewater treatment process, nitrification and denitrification proceed simultaneously in a single tank, so it is not clear which reaction is the principal cause of emissions of $\mathrm{N}_{2} \mathrm{O}$. In practice, it is known that $\mathrm{N}_{2} \mathrm{O}$ emissions increase to accumulate nitrite $\left(\mathrm{NO}_{2}{ }^{-}\right)$or nitrate $\left(\mathrm{NO}_{3}{ }^{-}\right)$in both the nitrification and denitrification stages $[2,4]$. In the current study, $\mathrm{N}_{2} \mathrm{O}$ gas from wastewater treatment using the activated sludge process was monitored for one year. Kosonen et al. reported annual $\mathrm{N}_{2} \mathrm{O}$ emissions of $168 \mathrm{~g} / \mathrm{PE} /$ year and $0.019 \mathrm{~g}$ $\mathrm{N}_{2} \mathrm{O}-\mathrm{N} / \mathrm{g} \mathrm{N}$ load from a fully covered underground wastewater treatment plant [5]. Daelman et al. reported $\mathrm{N}_{2} \mathrm{O}$ emissions of $0.028 \mathrm{~g} \mathrm{~N}_{2} \mathrm{O}-\mathrm{N} / \mathrm{g} \mathrm{N}$ load from a full-scale municipal wastewater treatment plant [3]. The $\mathrm{N}_{2} \mathrm{O}$ emission factor for the treatment of swine wastewater is $0.0287 \mathrm{~g} \mathrm{~N}_{2} \mathrm{O}-\mathrm{N} / \mathrm{g} \mathrm{N}$ load according to the 2015 National GHG Inventory Report of Japan (NIES 2015) [6]. The $\mathrm{N}_{2} \mathrm{O}$ emission factor of the activated sludge process has a similar value regardless of the category of the industry.

Among the current reports that describe technology for reducing $\mathrm{N}_{2} \mathrm{O}$ in the field of wastewater treatment, Sun et al. reported that the oxidation ditch process is a more effective method for $\mathrm{N}_{2} \mathrm{O}$ reduction from wastewater treatment than the anoxic-oxic process and sequencing batch reactor. The emission factor of the oxidation ditch process was $0.0025 \mathrm{~N}_{2} \mathrm{O}-\mathrm{N} / \mathrm{g} \mathrm{N}$ load [7]. Their report indicates that to encourage denitrification, it is necessary to control DO concentration at an appropriate level and raise the rate of organic matter utilization in influent. Massara et al. reported that there are several $\mathrm{N}_{2} \mathrm{O}$ mitigation strategies. In these strategies, operators select the optimal operational conditions such as aeration rate and DO. Wastewater treatment operates at an optimal combination of $\mathrm{pH} 7$ and water temperature of $20^{\circ} \mathrm{C}$. It uses models to predict the $\mathrm{N}_{2} \mathrm{O}$ hotspots [8]. Santín also reported that it is important to control the $\mathrm{DO}$ for $\mathrm{N}_{2} \mathrm{O}$ reduction [9]. Zhang et al. reported that the $\mathrm{N}_{2} \mathrm{O}$ emission from synthetic nitrogen-rich wastewater could be reduced by four-tenths by using mannitol as the carbon source [10]. Meanwhile, in the field of livestock wastewater treatment, in particular, only a few such reports are available [11-13].

Consequently, we utilized biofilms to develop treatment methods capable of reducing $\mathrm{N}_{2} \mathrm{O}$ emissions. We expected redox reactions in the biofilm method to be different from those in the activated sludge (AS) method. The biofilm method proposed in this study involves the use of carriers where microbes can attach and consequently enhance wastewater treatment. Carbon fibres (CFs) were employed as the carrier here because microbes adhere thickly to CFs and remain on them for longer durations and at higher biomass concentrations than what is possible in the AS method. The biofilms grown on CFs become thick and they can hold both aerobic microorganisms and anaerobic microorganisms. The CFs expand by themselves when soaked in water. Biofilms form on these expanded CFs and assist in the treatment of wastewater using the AS method. In a previous laboratory-scale test, in which we investigated an aeration tank fixed with a CF carrier during AS treatment of swine wastewater effluent, we successfully reduced the $\mathrm{N}_{2} \mathrm{O}$ emissions by more than $60-90 \%$ compared to those generated by a system not fixed with the carrier $[4,13]$. The biochemical oxygen demand (BOD) treatment performance in this test was, at a minimum, on par with that of a device not filled with the carrier and the accumulation of $\mathrm{NO}_{3}{ }^{-}$and $\mathrm{NO}_{2}{ }^{-}$ions in the treated water was remarkably low. Thus, the proposed system was able to substantially reduce $\mathrm{N}_{2} \mathrm{O}$ emissions and improve the wastewater treatment performance [4].

In this study, with the goal of enabling practical use of the technology, firstly, to determine the reproducibility of $\mathrm{N}_{2} \mathrm{O}$ emission reduction from a full-scale swine wastewater treatment plant, we investigated the performance of an aerobic bioreactor packed with CFs (ca. $1 \mathrm{~m}^{3}$ bioreactor), as an alternative to conventional AS treatment under conditions that involved fluctuating water temperatures. Furthermore, we performed an experiment that verified, as shown by previous results, that inserting a CF carrier into an actual wastewater treatment plant can reduce the generation of $\mathrm{N}_{2} \mathrm{O}$ during six months of operation. 


\section{Materials and Methods}

\subsection{Bioreactor Construction and Operation}

The experiments were performed in a wastewater treatment plant at a swine farm ( 6000 heads) located in Okayama Prefecture, Japan. Figure 1 shows the treatment flow of this plant. The plant, which performs continuous aeration, uses the membrane bioreactor (MBR) method for wastewater treatment. For details of the operating conditions of this plant and the quality of the treated water, see the report by Osada et al. [14]. In this study, two experiments were performed; namely, a comparison experiment using a $1 \mathrm{~m}^{3}$ scale bioreactor and an experiment conducted by directly inserting the carrier into the actual plant.

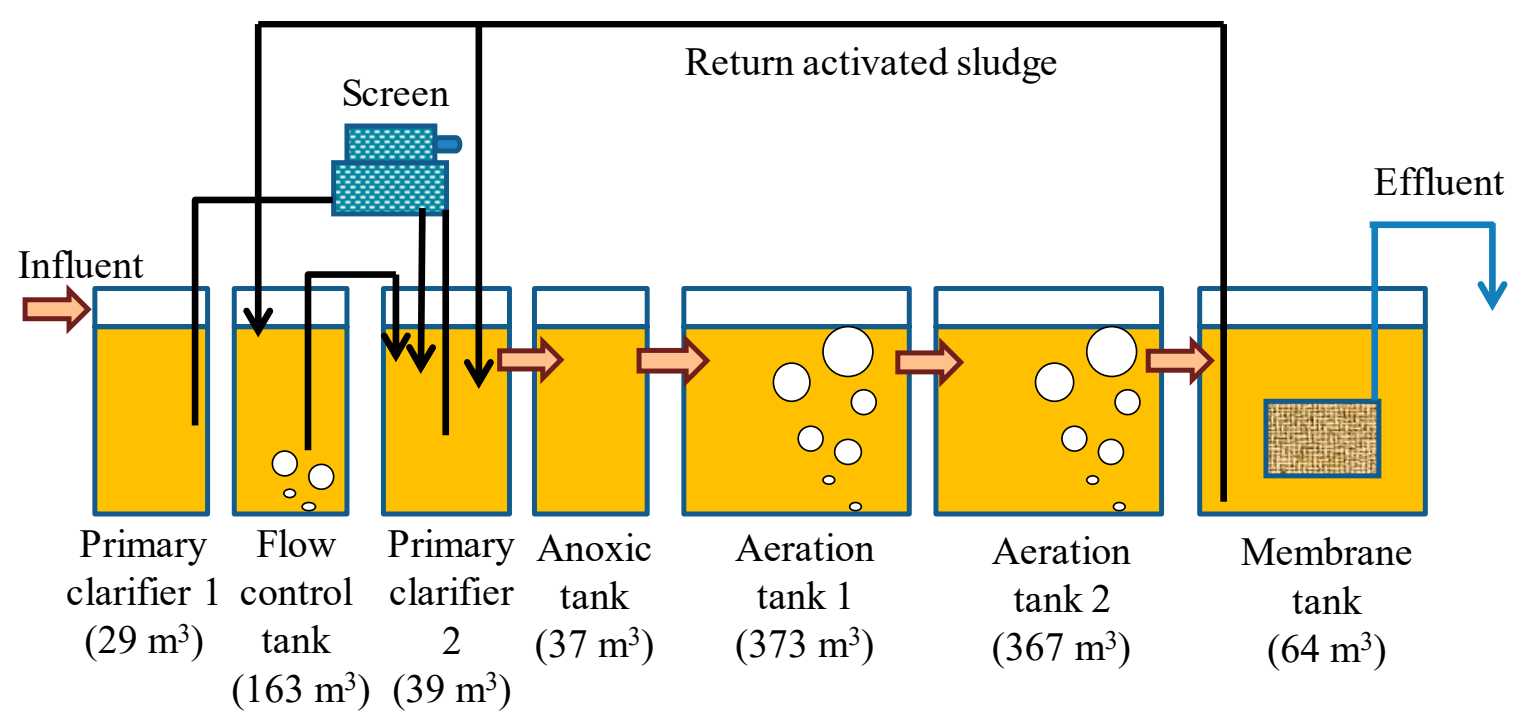

Figure 1. Schematic of the wastewater treatment plant for the swine farm in Okayama Prefecture.

The operating characteristics of the aerobic bioreactor are shown in Table 1. We first used equipment with a $1 \mathrm{~m}^{3}$ capacity for wastewater to perform an initial experiment to collect data useful for demonstrating the performance of the system (Figure 2). One aerobic bioreactor was packed with carbon fibres (CF reactor) and a second was mixed with activated sludge (AS reactor). The influent used was the effluent from the primary clarifier 1 in the wastewater treatment plant. The flow rate of the influent was approximately $30 \mathrm{~L} /$ day. The hydraulic retention time (HRT) was calculated to be about 23 days and the BOD loading rate was $0.43 \mathrm{~kg} / \mathrm{m}^{3} /$ day. The experiment was performed outdoors, so the water temperature fluctuated. The aeration rate in both the CF reactor and the AS reactor was $6 \mathrm{~m}^{3} / \mathrm{h}$. Effluent from the bioreactors was collected as supernatant liquid in the secondary tanks. Samples of bioreactor influent and effluent were collected once per week and BOD, chemical oxygen demand (COD), suspended solids (SS), total nitrogen ( $\mathrm{TN}$ ), $\mathrm{NH}_{4}-\mathrm{N}, \mathrm{NO}_{2}-\mathrm{N}, \mathrm{NO}_{3}-\mathrm{N}$, total phosphorus (TP) and pH were measured. Diurnal fluctuations in water temperature and dissolved oxygen (DO) in the liquid layer of the aerobic bioreactors were also measured. The amount of mixed liquor suspended solids (MLSS) was measured once per week. In addition, concentrations of $\mathrm{N}_{2} \mathrm{O}$ in the emissions from the reactors were measured.

For the $\mathrm{N}_{2} \mathrm{O}$ generation reduction experiment performed by introducing CFs into the actual plant, the CF carrier was placed in a portion of aeration tank 2 of the treatment plant. The CFs (T700SC-24000, Toray Industries, Inc., Tokyo, Japan), shown in Figure S1, were cut to a length of $50 \mathrm{~cm}$ and 20 units of carriers with 300 of these attached in parallel at intervals of $1 \mathrm{~cm}$ were installed. The quantity of the GHG generated was monitored for six months. The operating conditions of the treatment plant during the experimental period were as follows. The flow rate of the influent was $20 \mathrm{~m}^{3} /$ day. The HRT was calculated to be 37 days and the BOD loading rate was $0.3 \mathrm{~kg} / \mathrm{m}^{3} /$ day. The aeration 
rate in the aeration tank was $15 \mathrm{~m}^{3} / \mathrm{min}$. The gas was measured in accordance with the method reported by Osada et al. [14] and the water quality was analysed using the same method described above; these methods are described briefly in the next section.

Table 1. Aerobic bioreactor operating characteristics.

\begin{tabular}{lcc}
\hline & AS Reactor & CF Reactor \\
\hline Bioreactor & & \\
\hline Height $(\mathrm{cm})$ & 110 & 110 \\
Width $(\mathrm{cm})$ & 90 & 90 \\
Depth $(\mathrm{cm})$ & 90 & 90 \\
Water phase $(\mathrm{L})$ & 700 & 700 \\
\hline Carbon Fiber Carrier & & \\
\hline Diameter $(\mu \mathrm{m})$ & - & 7 \\
Number of fibers & - & 24,000 \\
Length $(\mathrm{cm})$ & - & 25 \\
\hline Fixed carbon fiber units & - & 104 \\
Feed cycle $(\mathrm{h})$ & 24 & 24 \\
Average feed volume $(\mathrm{L} /$ day) & 30 & 30 \\
Aeration rate $\left(\mathrm{m}^{3} / \mathrm{h}\right)$ & 6 & 6 \\
\hline
\end{tabular}

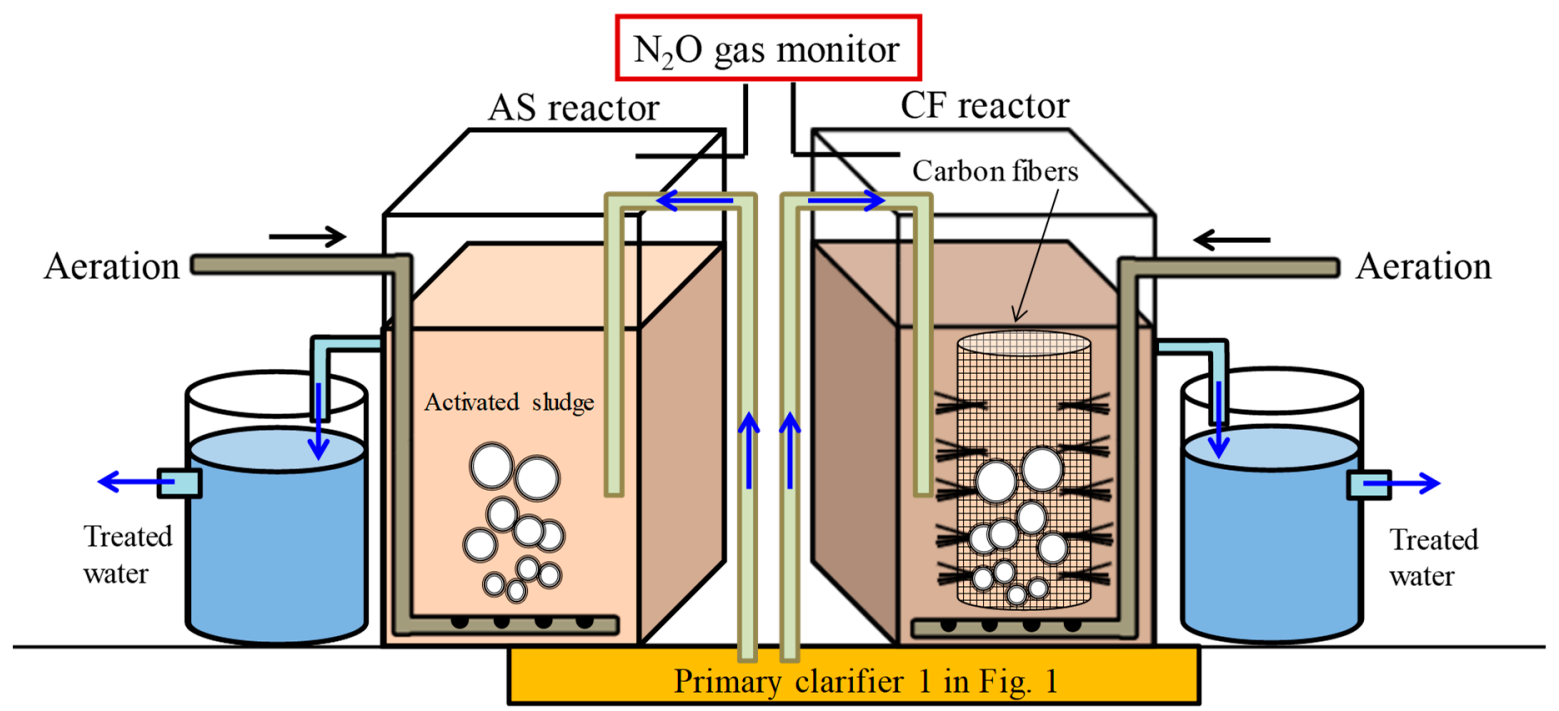

Figure 2. Schematic of the bioreactors.

\subsection{Analytical Methods for Determining Water Quality and Measuring $\mathrm{N}_{2} \mathrm{O}$ Emissions}

Water temperature was measured with a TR-72 temperature and humidity data logger (T\&D Corporation, Nagano, Japan). The DO was measured with a YSI 626281 ProODO Optical Dissolved Oxygen Meter (Xylem Japan [YSI/Nanotech, Ltd.], Kanagawa, Japan). These measurements were taken at a depth of $30 \mathrm{~cm}$ below the water surface. The $\mathrm{pH}$ was determined with a glass electrode. The BOD was determined by a modified procedure using sodium azide and COD was determined by heating with potassium permanganate for $30 \mathrm{~min}$. The SS was assessed according to Standard Methods for the Examination of Water and Wastewater [15] by using glass-fibre filters. The TN was determined by using an ultraviolet spectrophotometric method. Statistical analyses were conducted with the R Statistical Computing Environment version 3.1.1. The results were reported as the mean and standard deviation (SD). The concentrations of $\mathrm{NH}_{4}-\mathrm{N}, \mathrm{NO}_{2}-\mathrm{N}$ and $\mathrm{NO}_{3}-\mathrm{N}$ were determined by the Bremner method. $\mathrm{N}_{2} \mathrm{O}$ emissions from the reactor were measured at 10-min intervals with an Innova 1312 Multi Gas Monitor (LumaSense Technologies, Santa Clara, CA, USA). 


\subsection{Characterization of Bacterial Species}

Next-generation sequencing was performed by using the MiSeq Illumina sequencing platform (Illumina Inc., San Diego, CA, USA) on the V4 region of the 16S rRNA gene [16]. After the bioreactor was operated with the swine wastewater for four months, a portion of the $\mathrm{CF}$ was sampled. This $\mathrm{CF}$ material was extensively washed with distilled water until visible biofilms were washed out. Then, the washed portion of the fibre was cut off and the genomic DNA of the bacteria tightly attached to the fibre was extracted with an UltraClean ${ }^{\mathrm{TM}}$ Soil DNA Isolation Kit (Mo Bio Laboratories, Carlsbad, CA, USA). Libraries were constructed from bacterial genomic DNA via a polymerase chain reaction using $563 \mathrm{~F}$ and $802 \mathrm{R}$ primers, which included Illumina overhang adapter sequences. The libraries were sequenced on a 300PE MiSeq run and paired-end read data were processed with QIIME software [17]. The read sequences were joined, quality-checked and clustered into operational taxonomic units (OTUs) via the Uclust method [18]. After a chimera check, taxonomic classification, rarefaction curves and alpha diversity indices were computed with QIIME.

\section{Results}

\subsection{Water Quality and Gas Emissions from the Bioreactor}

The average water qualities of the influent and effluent during bioreactor operation are shown in Table 2. The MLSS amount was approximately $8000 \mathrm{mg} / \mathrm{L}$ in both the AS and the CF reactors. The average BOD, SS, COD and TN removal efficiencies in the AS reactor were $99.8 \%, 99 \%, 97 \%, 88 \%$, respectively. Dissolved inorganic nitrogen (DIN) removal as $\mathrm{NH}_{4}-\mathrm{N}$ was an average of approximately $1400 \mathrm{mg} / \mathrm{L}$ in the AS reactor and the average $\mathrm{NO}_{3}-\mathrm{N}$ and $\mathrm{NO}_{2}-\mathrm{N}$ accumulated was $282 \mathrm{mg} / \mathrm{L}$. The average BOD, SS, COD and TN removal efficiencies in the CF reactor were $99.8 \%, 99 \%, 97 \%$, $89 \%$, respectively. DIN removal as $\mathrm{NH}_{4}-\mathrm{N}$ was an average of approximately $1400 \mathrm{mg} / \mathrm{L}$ in the $\mathrm{CF}$ reactor and the average $\mathrm{NO}_{3}-\mathrm{N}$ and $\mathrm{NO}_{2}-\mathrm{N}$ accumulated was $195 \mathrm{mg} / \mathrm{L}$. A statistically significant difference $(p<0.05)$ between the AS and CF reactors was observed in terms of the accumulation of $\mathrm{NO}_{3}{ }^{-}$and $\mathrm{NO}_{2}{ }^{-}$(Figure 3). The range of $\mathrm{pH}$ in the $\mathrm{AS}$ reactor was 5.9 to 8.0 and the range of $\mathrm{pH}$ in the $\mathrm{CF}$ reactor was 6.9 to 7.9 . The $\mathrm{pH}$ of the AS reactor tended to decrease during the accumulation of $\mathrm{NO}_{3}{ }^{-}$and $\mathrm{NO}_{2}{ }^{-}$. The average $\mathrm{DO}$ was $1.3 \mathrm{mg} / \mathrm{L}$ in the $\mathrm{AS}$ reactor and $2.0 \mathrm{mg} / \mathrm{L}$ in the $\mathrm{CF}$ reactor. The average water temperature was $23.8 \pm 5.7^{\circ} \mathrm{C}$ in the AS reactor and $24.1 \pm 5.3^{\circ} \mathrm{C}$ in the $\mathrm{CF}$ reactor.

Table 2. Water qualities of the influent and effluent flow in this study.

\begin{tabular}{cccc}
\hline & Influent & Effluent from AS Reactor & Effluent from CF Reactor \\
\hline MLSS (mg/L) & - & $8301 \pm 455$ & $7542 \pm 835$ \\
$\mathrm{BOD}(\mathrm{mg} / \mathrm{L})$ & $9936 \pm 2179$ & $20 \pm 25$ & $19 \pm 23$ \\
$\mathrm{COD}(\mathrm{mg} / \mathrm{L})$ & $5898 \pm 2654$ & $181 \pm 80$ & $170 \pm 69$ \\
$\mathrm{SS}(\mathrm{mg} / \mathrm{L})$ & $12,972 \pm 7870$ & $90 \pm 39$ & $139 \pm 86$ \\
$\mathrm{TN}(\mathrm{mg} / \mathrm{L})$ & $2658 \pm 1002$ & $311 \pm 116$ & $300 \pm 103$ \\
$\mathrm{NH}_{4}{ }^{+}-\mathrm{N}(\mathrm{mg} / \mathrm{L})$ & $1392 \pm 321$ & $4 \pm 5$ & $4 \pm 6$ \\
$\mathrm{NO}_{2}{ }^{-}-\mathrm{N}(\mathrm{mg} / \mathrm{L})$ & $5 \pm 8$ & $48 \pm 68$ & $26 \pm 44$ \\
$\mathrm{NO}_{3}{ }^{-} \mathrm{N}(\mathrm{mg} / \mathrm{L})$ & $5 \pm 4$ & $234 \pm 137$ & $169 \pm 73$ \\
$\mathrm{TP}(\mathrm{mg} / \mathrm{L})$ & $412 \pm 152$ & $90 \pm 34$ & $69 \pm 29$ \\
$\mathrm{pH}$ & 6.7 to 7.8 & 5.9 to 8.0 & 6.9 to 7.9 \\
\hline
\end{tabular}

AS, activated sludge; CF, carbon fiber; MLSS, mixed liquor suspended solids; BOD, biochemical oxygen demand; COD, chemical oxygen demand; SS, suspended solids; TN, total nitrogen; TP, total phosphorus.

In situ measurements of $\mathrm{N}_{2} \mathrm{O}$ emissions from the $\mathrm{AS}$ and $\mathrm{CF}$ reactors during operation are shown in Figure 4. The gas emissions from the AS reactor amounted to $1824 \mathrm{mg} /$ day of $\mathrm{N}_{2} \mathrm{O}$. The gas emissions from the CF reactor amounted to $270 \mathrm{mg} /$ day of $\mathrm{N}_{2} \mathrm{O}$. Thus, the $\mathrm{N}_{2} \mathrm{O}$ emissions from the AS reactor were significantly higher than those from the $\mathrm{CF}$ reactor. The global warming potential (an 
index for the contribution of atmospheric GHGs to global warming) was calculated in accordance with Intergovernmental Panel on Climate Change (IPCC) 2013 statutes [19], considering $\mathrm{CO}_{2}$ eq; the values obtained were 1 for $\mathrm{CO}_{2}$ and 298 for $\mathrm{N}_{2} \mathrm{O}$. The $\mathrm{N}_{2} \mathrm{O}$ emissions from the AS and CF reactors were determined to be 777 and $115 \mathrm{~g} \mathrm{CO}_{2} \mathrm{eq} / \mathrm{m}^{3}$. day, respectively. The $\mathrm{N}_{2} \mathrm{O}$ emission factors were $0.013 \mathrm{~g}$ $\mathrm{N}_{2} \mathrm{O}-\mathrm{N} / \mathrm{g}$ TN-load and $0.002 \mathrm{~g} \mathrm{~N}_{2} \mathrm{O}-\mathrm{N} / \mathrm{g}$ TN-load in the AS and CF reactors, respectively. These data indicate that more than $80 \%$ of $\mathrm{N}_{2} \mathrm{O}$ emissions from the swine wastewater treatment process could be inhibited by using the $\mathrm{CF}$ reactor instead of the AS reactor.

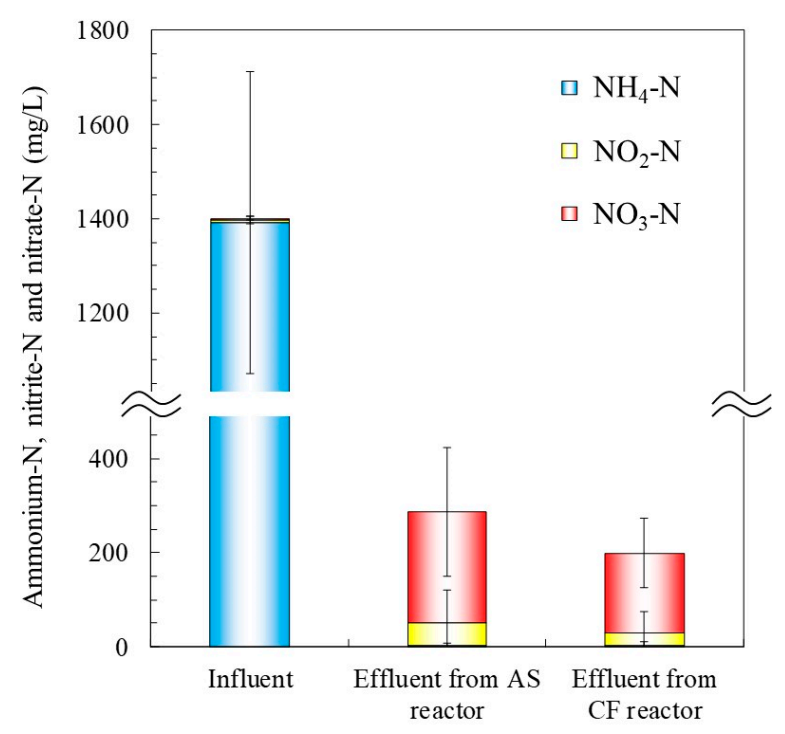

Figure 3. Influent and effluent concentrations of $\mathrm{NH}_{4}-\mathrm{N}, \mathrm{NO}_{2}-\mathrm{N}$ and $\mathrm{NO}_{3}-\mathrm{N}$ in the reactors during operation.

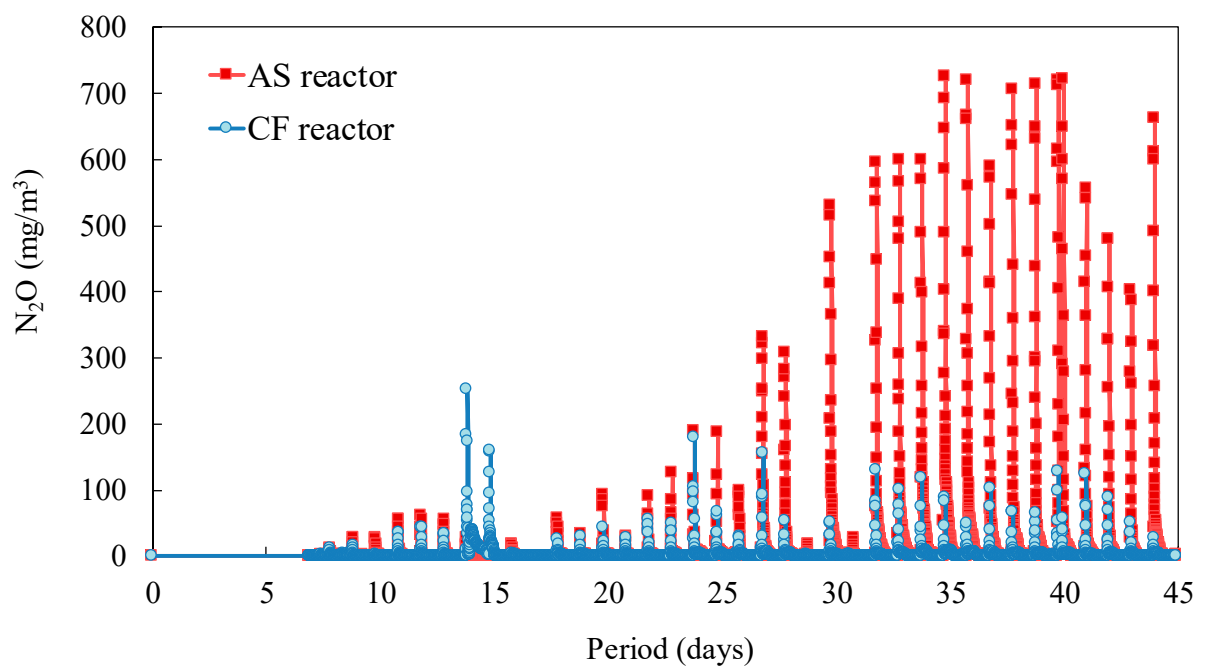

Figure 4. Time series of gas emissions of $\mathrm{N}_{2} \mathrm{O}$ in the bioreactors.

\subsection{Bacterial Community Structure of the Biofilms in the Bioreactor}

Bacterial community analyses of the samples collected from the AS reactor (AS), the biofilms adhering to the surfaces of the CFs in the CF reactor (CF-biofilm (SL)) and the biofilms adhering to the inside of the CFs in the CF reactor (CF-biofilm (DL)) were performed. In all samples, Planctomycetes and Chloroflexi were detected at high frequencies (27-32\% and $15-27 \%$, respectively) and Proteobacteria and Bacteroidetes were the second most abundant types present $(8-14 \%$ and $5-10 \%$, respectively) (Figure 5). Chloroflexi was more abundant in the biofilms of the CF reactor (23-27\%) than 
in the AS (15\%) but no other significant differences were detected in the comparisons between the AS and the biofilms of the CF reactor. In the order-to-genus level analysis (Figure 6), the genus Planctomyces was observed at a higher frequency in the CF-biofilm (SL) sample (12\%) than in the AS sample (7\%). The phylum Chloroflexi occurred at higher frequencies in the CF-biofilm (SL) and CF-biofilm (DL) samples (18-27\%) than in the AS sample (13\%), and, especially, the family Caldilineaceae was observed at a significantly higher frequency in the CF-biofilm (SL) sample (16\%) than in the AS sample (5\%). The order envOPS12 was observed at a significantly higher frequency in the CF-biofilm (DL) sample $(7 \%)$ than in the AS sample (1\%). The family Chthonomonadaceae was observed at a higher frequency in the CF-biofilm (SL) sample (4\%) than in the AS sample (1\%). Additionally, the order WD2101 and the family Cytophagaceae were observed at significantly higher frequencies in the AS sample $(6 \%$ and $4 \%$, respectively) than in the CF-biofilm (SL) and CF-biofilm (DL) samples ( $2-3 \%$ and $1 \%$, respectively).

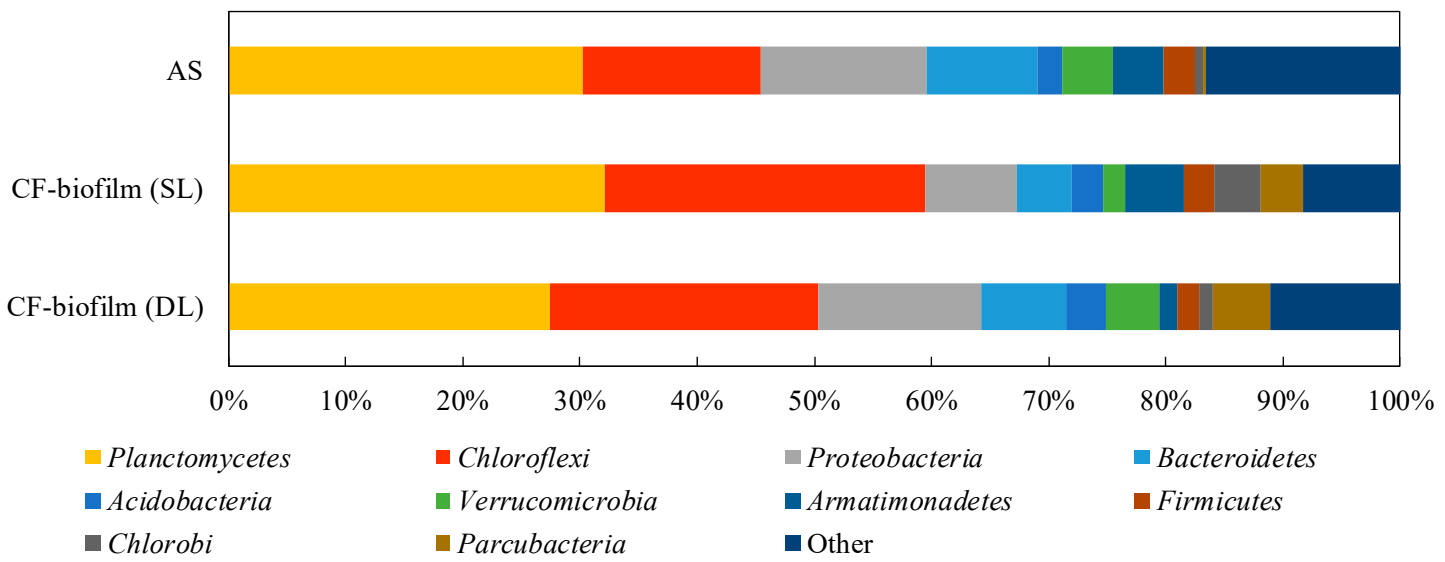

Figure 5. Phylum distribution within the activated sludge in the AS reactor and the biofilm formed on the carbon fibres (CF) in the CF reactor.

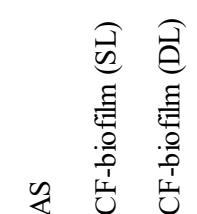

\begin{tabular}{|c|c|c|}
\hline 7 & 12 & 5 \\
\hline 11 & 9 & 8 \\
\hline 0 & 1 & 2 \\
\hline 1 & 2 & 0 \\
\hline 6 & 2 & 3 \\
\hline 7 & 9 & 6 \\
\hline 5 & 16 & 5 \\
\hline 1 & 1 & 7 \\
\hline 1 & 1 & 2 \\
\hline 4 & 1 & 1 \\
\hline 1 & 2 & 2 \\
\hline 0 & 4 & 1 \\
\hline 55 & 40 & 57 \\
\hline
\end{tabular}

$\begin{array}{lll}\begin{array}{l}\text { Order } \\ \text { Planctomycetales }\end{array} & \begin{array}{l}\text { Family } \\ \text { Planctomycetaceae }\end{array} & \begin{array}{l}\text { Genus } \\ \text { Planctomyces }\end{array} \\ \text { Pirellulales } & \text { Pirellulaceae } & \\ \text { Pla1 } & & \\ \text { Gemmatales } & \text { Gemmataceae } & \text { Gemmata } \\ \text { WD2101 } & & \\ \text { Caldilineales } & \text { Caldilineaceae } & \text { Caldilinea } \\ \text { Caldilineales } & \text { Caldilineaceae } & \\ \text { envOPS12 } & & \\ \text { Burkholderiales } & \text { Comamonadaceae } & \\ \text { Cytophagales } & \text { Cytophagaceae } & \\ \text { RB41 } & \text { Ellin6075 } & \\ \text { Chthonomonadales } & \text { Chthonomonadaceae } & \\ & \end{array}$

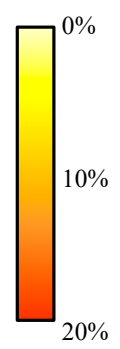

Figure 6. Phylogenetically clustered heat map of the major orders identified in microbial communities of the bioreactor based on analysis of the 16S rRNA gene. 


\section{3. $\mathrm{N}_{2} \mathrm{O}$ Generation Reduction Following Introduction of Carbon Fiber into the Actual Plant}

The CF carrier was inserted into the actual wastewater treatment plant and the quantities of GHG generated were monitored. The average $\mathrm{DO}$, water temperature and $\mathrm{pH}$ in the wastewater treatment plant during the monitoring period were $4.4 \pm 1.7 \mathrm{mg} / \mathrm{L}, 21.8 \pm 4.0^{\circ} \mathrm{C}$ and $7.4-8.2$, respectively. The average TN was $2132 \pm 545 \mathrm{mg} / \mathrm{L}$ in the influent and $157 \pm 31 \mathrm{mg} / \mathrm{L}$ in the effluent (the treated wastewater). The average quantity of $\mathrm{N}_{2} \mathrm{O}$ generated prior to $\mathrm{CF}$ carrier insertion was $2500 \mathrm{~g} /$ day; following CF carrier insertion, the average was reduced to less than $300 \mathrm{~g} /$ day (Figure 7).

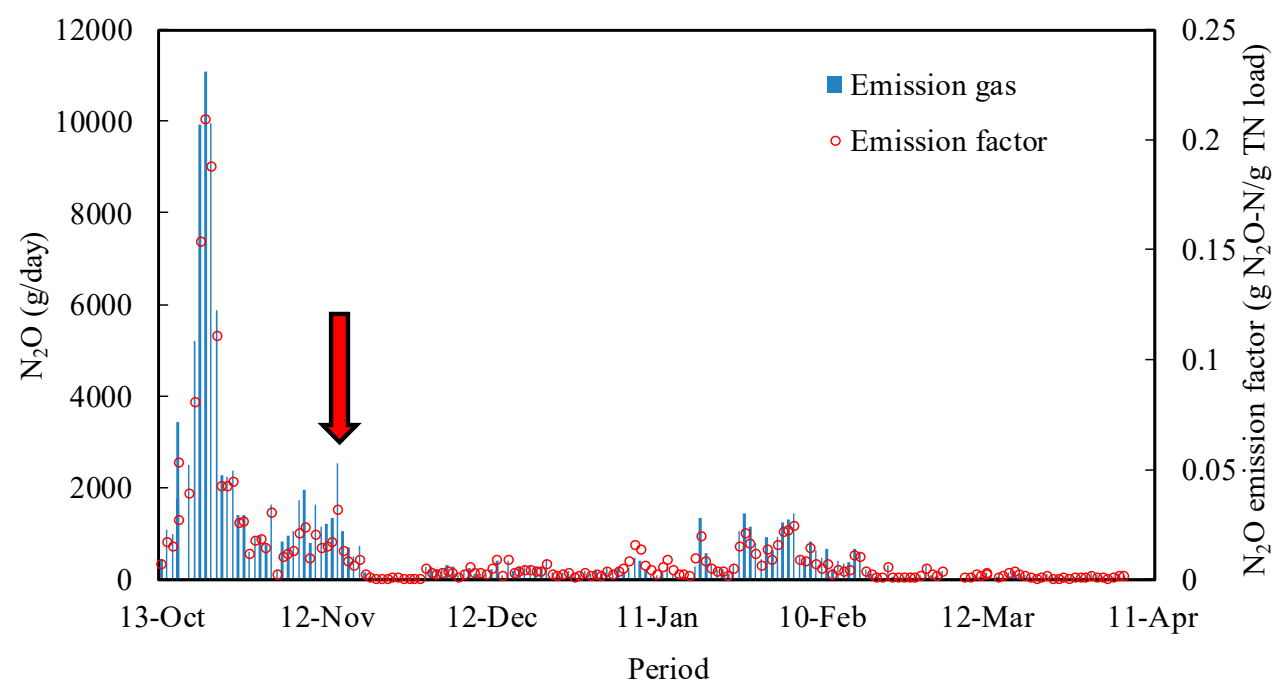

Figure 7. Time series of emission gas and emission factor of $\mathrm{N}_{2} \mathrm{O}$ in the wastewater treatment plant for the swine farm. The time at which the carbon fibre carriers were applied is indicated by the red arrow.

The $\mathrm{N}_{2} \mathrm{O}$ emission factors decreased from 0.040 to $0.005 \mathrm{~g} \mathrm{~N} \mathrm{~N}_{2} \mathrm{O}-\mathrm{N} / \mathrm{g}$ TN-load following application of the carrier. Conversely, methane and ammonia gas, which were also monitored during the period of the experiment, showed no significant differences between the results before and after insertion of the CF carrier (Figures S2 and S3).

\section{Discussion}

The AS method is the treatment method that is generally applied in wastewater treatment plants. This method involves feeding air to floc-like AS to remove organic matter from the wastewater. An aerobic environment exists within the aeration tank. Therefore, $\mathrm{NH}_{4}{ }^{+}$in the wastewater is converted to $\mathrm{NO}_{3}{ }^{-}$and $\mathrm{NO}_{2}{ }^{-}$by nitrification under the aerobic conditions but in many cases, most of these ions are not denitrified. It is possible to encourage denitrification to remove nitrogen by performing intermittent aeration but because the organic material removal capacity achieved by intermittent aeration is inferior to that of the continuous aeration method, it can be stated that the method is not suited for wastewater treatment plants with high BOD loads or wastewater treatment plants that treat source water such as swine wastewater with high organic matter concentrations. On the other hand, Sabba et al. reported that nitrate reduction occurs when the $\mathrm{O}_{2}$ concentration approaches zero in the case where biofilm thickness is below $320 \mu \mathrm{m}$ and conditions are aerobic [20]. The formation of thick biofilms (the thickness was $>1 \mathrm{~mm}$ ) by the CF carrier creates an ecological niche in both the aerobic region and the anaerobic region. Nitrifying bacteria that prefer aerobic conditions and denitrifying bacteria that prefer anaerobic conditions coexist in a single tank and the microorganisms mature under conditions that minimize external stress, thus resulting in restriction of the generation of excess $\mathrm{N}_{2} \mathrm{O}$. Hence, less $\mathrm{N}_{2} \mathrm{O}$ is generated than in the case of AS treatment. Moreover, the CF reactor utilized in this study can treat organic matter up to levels handled by the AS reactor. In addition, the CF reactor has improved wastewater treatment functions because of the reduced amounts of $\mathrm{NO}_{3}{ }^{-}$and $\mathrm{NO}_{2}{ }^{-}$ 
remaining in the treated water. Judging from the gas emission measurement results, more than $80 \%$ of the $\mathrm{N}_{2} \mathrm{O}$ emissions from the swine wastewater treatment process were inhibited by using the $\mathrm{CF}$ reactor instead of the AS reactor. This suggests that treatment without the accumulation of $\mathrm{NO}_{3}{ }^{-}$and $\mathrm{NO}_{2}{ }^{-}$is important for $\mathrm{N}_{2} \mathrm{O}$ emission reductions.

According to the results of the microbial community analyses, microbial communities that contributed to nitrogen removal were detected from the biofilms of the CF reactor in larger quantities than in the AS reactor. Caldilinea aerophile, of the family Caldilineaceae and belonging to the phylum Chloroflexi, are multicellular filamentous organisms that are capable of fermentative metabolism and $\mathrm{O}_{2}$ respiration [21,22]. The genus Caldilinea is affiliated with Eikelboom type 0803 [23]. Eikelboom types are filamentous bacteria that have been isolated from AS [24,25]. Sanford et al. indicated that a part of the phylum Chloroflexi is capable of $\mathrm{N}_{2} \mathrm{O}$ to $\mathrm{N}_{2}$ reduction [26]. As bacteria of the phylum Chloroflexi were more significantly detected in the CF-biofilm than in AS, it implies that the phylum Chloroflexi contributed to reducing $\mathrm{N}_{2} \mathrm{O}$ emission to adhere within the $\mathrm{CF}$ carrier. In addition, the order envOPS12, which belongs to the phylum Chloroflexi, has been found in a wide range of anaerobic environments, such as freshwater, sediments, marine water, sponges, anaerobic sludge bioreactors and anammox reactors $[27,28]$. Because envOPS12 grows in anaerobic conditions, it was hypothesized that a large quantity of envOPS12 was detected because the CF-biofilm (DL) was in an anaerobic condition. Certain members of the phylum Planctomycetes, which are conventional ammonia oxidizers, oxidize $\mathrm{NH}_{4}{ }^{+}$and $\mathrm{NO}_{2}{ }^{-}$to $\mathrm{N}_{2}$ [29]. The genus Planctomyces is capable of oxidizing $\mathrm{NH}_{4}{ }^{+}$ under anaerobic conditions, such as by anammox [30]. More bacteria of the genus Planctomyces were detected in the CF-biofilm than in AS, which suggests that this microbial community might have contributed to the removal of nitrogen. The family Chthonomonadaceae belongs to the phylum Armatimonadetes, which includes aerobic bacteria that have been isolated from geothermally heated soil [31]. The CF-biofilm (SL) sample was taken from the surface of the CF, so it was hypothesized that the family Chthonomonadaceae bacteria detected there proliferated in an aerobic condition. However, this group was almost completely undetected in the AS sample regardless of aerobic conditions. The family Cytophagaceae belongs to the phylum Bacteroidetes, which consists of heterotrophic and mostly aerobic bacteria that engage in primarily respiratory metabolism [32]. The order WD2101 was recently assigned to the order Tepidisphaerales. The order Tepidisphaerales consists of moderately thermophilic and facultative aerobic bacteria that have been isolated from terrestrial hot springs [33]. It is thought that the above-described family Cytophagaceae and the order WD2101 were detected at higher levels in the AS treatment because the entire interior of the tanks in this treatment comprised an aerobic environment.

It can be assumed that the generation of the GHG $\mathrm{N}_{2} \mathrm{O}$ is related to a variety of causes, not only in the livestock industry but also in all wastewater treatment operations [2]. Wunderlin et al. [34] reported on the generation of $\mathrm{N}_{2} \mathrm{O}$ in experimental studies of both the nitrification reaction (aerobic conditions) and the denitrification reaction (anaerobic conditions) in municipal wastewater treatment operations and it was thought that the two reactions interacted in the tank to generate $\mathrm{N}_{2} \mathrm{O}$. As noteworthy causes of the generation of $\mathrm{N}_{2} \mathrm{O}$ in tanks, the $\mathrm{DO}$ concentration, $\mathrm{COD} / \mathrm{N}$ ratio and $\mathrm{pH}$ are often cited. The DO concentration in a tank is an important parameter that controls the generation of $\mathrm{N}_{2} \mathrm{O}$ [35] and it is thought that limiting the DO concentration during the nitrification reaction may lead to the generation of $\mathrm{N}_{2} \mathrm{O}$ by the reaction pathway of denitrification (reduction), rather than by the oxidization pathway by nitrifying bacteria [36]. In the denitrification reaction, oxygen restricts the synthesis and activation of denitrification enzymes but because nitrous oxide reductase reacts with and is restricted more sensitively by oxygen than other enzymes, it has been pointed out that even if the oxygen concentration is low, generation of $\mathrm{N}_{2} \mathrm{O}$ might be encouraged during the denitrification reaction process [37]. The $\mathrm{COD} / \mathrm{N}$ ratio is another parameter that plays an important role in restricting the generation of $\mathrm{N}_{2} \mathrm{O}$. It is known that if the biodegradable organic matter concentration in the denitrification reaction decreases, more $\mathrm{N}_{2} \mathrm{O}$ is generated [38]. Hanaki et al. [39] reported that $\mathrm{N}_{2} \mathrm{O}$ emitted $10 \%$ of the maximum nitrogen load at the lowest COD/ $\mathrm{N}$ ratio; this result was based on 
denitrification experiments conducted for a variety of $\mathrm{COD} / \mathrm{NO}_{3}-\mathrm{N}$ ratios $(1.5,2.5,3.5$ and 4.5). In addition, Park et al. [40] reported that adding methanol as a source of organic carbon effectively suppresses the generation of $\mathrm{N}_{2} \mathrm{O}$. For this reason, it can be considered that treatment accompanied by control of the COD/N is important for reducing the generation of $\mathrm{N}_{2} \mathrm{O}$. In this study, the COD/N of the wastewater was approximately two but use of the CF carrier encouraged denitrification and thus successfully helped to reduce the generation of $\mathrm{N}_{2} \mathrm{O}$ below that of the AS system. The other parameter assumed to play an important role in reducing the generation of $\mathrm{N}_{2} \mathrm{O}$ is $\mathrm{pH}$. Thörn et al. [41] reported that $\mathrm{N}_{2} \mathrm{O}$ was generated during the denitrification process only when the $\mathrm{pH}$ was lower than 6.8. Additionally, Hanaki et al. [39] reported $\mathrm{N}_{2} \mathrm{O}$ being generated by the denitrification reaction when the $\mathrm{pH}$ was reduced from 8.5 to 6.5. In this study, the range of $\mathrm{pH}$ in the AS reactor was 5.9 to 8.0 and the range of $\mathrm{pH}$ in the $\mathrm{CF}$ reactor was 6.9 to 7.9. In the AS reactor, there was a time when the $\mathrm{pH}$ was lower than 6.8 , so this result supports the aforementioned reports. The accumulation of nitrite ions and nitrate ions likely contributed to the low $\mathrm{pH}$. In this study, in the AS and CF reactors, these components accumulated at an average of 282 and $195 \mathrm{mg} / \mathrm{L} \mathrm{NO}_{3}-\mathrm{N}$ and $\mathrm{NO}_{2}-\mathrm{N}$, respectively. The environment in the AS reactor was more aerobic than that in the CF reactor, so nitrite ions and nitrate ions accumulated easily in the AS reactor and the $\mathrm{pH}$ tended toward acidity. During AS treatment of municipal wastewater, the $\mathrm{pH}$ inside the reaction tanks typically varies around seven, so the above issue is not a concern but in the treatment of swine or dairy wastewater, the nitrogen concentration is high and the resulting nitrate ions and nitrite ions accumulate easily, which often leads to $\mathrm{pH}$ values lower than six. Therefore, it is important to observe carefully for any change of $\mathrm{pH}$ while operating such a system.

The results of the test with the $\mathrm{CF}$ carrier inserted into an actual treatment plant demonstrated the successful large-scale reduction of the generated $\mathrm{N}_{2} \mathrm{O}$ from 0.040 to $0.005 \mathrm{~g} \mathrm{~N}_{2} \mathrm{O}-\mathrm{N} / \mathrm{g}$ TN-load. A large quantity of $\mathrm{N}_{2} \mathrm{O}$ was generated before the $\mathrm{CF}$ carrier was inserted and according to the report by Osada et al. [14], referred to above, the $\mathrm{N}_{2} \mathrm{O}$ emission factor of this treatment system (Okayama 1) was $0.029 \mathrm{~g} \mathrm{~N}_{2} \mathrm{O}-\mathrm{N} / \mathrm{g}$ TN-load using this estimated value. We showed that it is possible to reduce the generation of $\mathrm{N}_{2} \mathrm{O}$ by more than $80 \%$ by using the $\mathrm{CF}$ carrier. In this experiment, the results were obtained after the placement of the carrier in a portion of the aeration tank, which did result in reduction of the generated $\mathrm{N}_{2} \mathrm{O}$, thus clearly showing the important role of the $\mathrm{CF}$ carrier. With regard to water quality, no conspicuous nitrite and nitrate ion accumulation reduction effects were found. The likely reason for this observation is that the carrier was placed in only about $10 \%$ of the volume of the reaction tanks of the treatment system, so a sufficient anaerobic environment could not form, which prevented denitrification. Therefore, it is presumed that if the anaerobic environment inside the tank could be improved by increasing the volume of CF placed, denitrification would be encouraged and this would reduce the accumulation of nitrite ions and nitrate ions. It was feared that inserting the CF carrier into an actual plant could harm plant operations but no particular troubles, such as clogging of pipes, mechanical failure of operating machinery, deterioration of the sludge or reduction of water quality, occurred during the experiment. The results of this study confirm that applying CFs in actual plants will not cause any problems.

\section{Conclusions}

With the goal of implementing technologies to reduce greenhouse gas (GHG) emissions to prevent global warming, we demonstrated a reduction in GHG emissions from a swine wastewater treatment plant following introduction of carbon fibre (CF) carrier equipment. The CF method has a biochemical oxygen demand (BOD) removal performance equal to that of the activated sludge (AS) method and its nitrogen removal performance was found to be superior to that of the AS method. The CF method also reduced the emissions of $\mathrm{N}_{2} \mathrm{O}$, a strong GHG. Similar to the results of past reports, the $\mathrm{N}_{2} \mathrm{O}$ generation reduction effect was high and the results were clearly very reproducible. In the bacterial community structure analysis, some bacteria from the phylum Chloroflexi, which are capable of reducing $\mathrm{N}_{2} \mathrm{O}$, were detected at a relatively high frequency in the biofilm on the CF carrier. This study 
also demonstrated that introducing a CF carrier into an actual plant can result in reductions of $\mathrm{N}_{2} \mathrm{O}$ emissions. The results of both experiments also show that it is possible to reduce $\mathrm{N}_{2} \mathrm{O}$ emissions by more than $80 \%$ by using a CF carrier. The CF method can be implemented in operational wastewater treatment plants without the need for accompanying special equipment. This reduces the initial investment cost. The CF method is, therefore, likely to be adopted for use in livestock farms and other areas. In the future, to reduce GHG emissions and improve water quality further, it will be necessary to verify the effectiveness of $\mathrm{CF}$ carriers under broader conditions.

Supplementary Materials: The following are available online at http:/ /www.mdpi.com/1996-1073/12/6/1013/ s1, Figure S1: Photograph of the carbon fibre carriers, Figure S2: Time series of gas concentrations of $\mathrm{CH}_{4}$ in the wastewater treatment plant for the swine farm. The time at which the carbon fibre carriers were applied is indicated by the red arrow, Figure S3: Time series of gas concentrations of $\mathrm{NH}_{3}$ in the wastewater treatment plant for the swine farm. The time at which the carbon fibre carriers were applied is indicated by the red arrow.

Author Contributions: Conceptualization, T.Y. and R.Y.-I.; methodology, T.Y. and T.O.; validation, M.S.; formal data analysis, A.O. and T.O.; experimental analysis, T.Y. and H.Y.; writing, T.Y. All authors read and approved the final manuscript.

Funding: This research was funded by the Ministry of Agriculture, Forestry and Fisheries of Japan, via a commissioned project, named "Development study for the mitigation measures for climate change in Livestock sector".

Acknowledgments: We thank Takeshi Mizuki and Mieko Yoshida for their skilful technical assistance with the experiments.

Conflicts of Interest: The authors declare no conflict of interest.

\section{References}

1. Eggleston, H.S.B.L.; Miwa, K.; Ngara, T.; Tanabe, K. (Eds.) Chapter 10: Emissions from Livestock and Manure Management in Volume 4 Agriculture, Forestry and Other Land Use. In IPCC (Intergovernmental Panel on Climate Change), 2006 IPCC Guidelines for National Greenhouse Gas Inventories, Prepared by the National Greenhouse Gas Inventories Programme; IPCC: Kanagawa, Japan, 2006.

2. Kampschreur, M.J.; Temmink, H.; Kleerebezem, R.; Jetten, M.S.M.; van Loosdrecht, M.C.M. Nitrous oxide emission during wastewater treatment. Water Res. 2009, 43, 4093-4103. [CrossRef] [PubMed]

3. Daelman, M.R.J.; van Voorthuizen, E.M.; van Dongen, U.G.J.M.; Volcke, E.I.P.; van Loosdrecht, M.C.M. Seasonal and diurnal variability of $\mathrm{N}_{2} \mathrm{O}$ emissions from a full-scale municipal wastewater treatment plant. Sci. Total Environ. 2015, 536, 1-11. [CrossRef] [PubMed]

4. Yamashita, T.; Yamamoto-Ikemoto, R.; Yokoyama, H.; Kawahara, H.; Ogino, A.; Osada, T. Mitigation of nitrous oxide $\left(\mathrm{N}_{2} \mathrm{O}\right)$ emission from swine wastewater treatment in an aerobic bioreactor packed with carbon fibers. Anim. Sci. J. 2015, 86, 358-368. [CrossRef] [PubMed]

5. Kosonen, H.; Heinonen, M.; Mikola, A.; Haimi, H.; Mulas, M.; Corona, F.; Vahala, R. Nitrous Oxide Production at a Fully Covered Wastewater Treatment Plant: Results of a Long-Term Online Monitoring Campaign. Environ. Sci. Technol. 2016, 50, 5547-5554. [CrossRef]

6. NIES. National Greenhouse Gas Inventory Report of Japan (NIR); Ministry of the Environment: Tokyo, Japan, 2015. Available online: http:/ / www-gio.nies.go.jp/aboutghg/nir/nir-e.html (accessed on 21 July 2014).

7. Sun, S.; Bao, Z.; Sun, D. Study on emission characteristics and reduction strategy of nitrous oxide during wastewater treatment by different processes. Environ. Sci. Pollut. Res. 2015, 22, 4222-4229. [CrossRef] [PubMed]

8. Massara, T.M.; Malamis, S.; Guisasola, A.; Baeza, J.A.; Noutsopoulos, C.; Katsou, E. A review on nitrous oxide $\left(\mathrm{N}_{2} \mathrm{O}\right)$ emissions during biological nutrient removal from municipal wastewater and sludge reject water. Sci. Total Environ. 2017, 596-597, 106-123. [CrossRef]

9. Santín, I.; Barbu, M.; Pedret, C.; Vilanova, R. Control strategies for nitrous oxide emissions reduction on wastewater treatment plants operation. Water Res. 2017, 125, 466-477. [CrossRef]

10. Zhang, X.; Wang, X.; Zhang, J.; Huang, X.; Wei, D.; Lan, W.; Hu, Z. Reduction of nitrous oxide emissions from partial nitrification process by using innovative carbon source (mannitol). Bioresour. Technol. 2016, 218, 789-795. [CrossRef] 
11. Osada, T.; Kuroda, K.; Yonaga, M. Reducing nitrous oxide gas emissions from fill-and-draw type activated sludge process. Water Res. 1995, 29, 1607-1608. [CrossRef]

12. Ikeda-Ohtsubo, W.; Miyahara, M.; Kim, S.W.; Yamada, T.; Matsuoka, M.; Watanabe, A.; Fushinobu, S.; Wakagi, T.; Shoun, H.; Miyauchi, K.; et al. Bioaugmentation of a wastewater bioreactor system with the nitrous oxide-reducing denitrifier Pseudomonas stutzeri strain TR2. J. Biosci. Bioeng. 2013, 115, $37-42$. [CrossRef]

13. Yamashita, T.; Shiraishi, M.; Yamamoto-Ikemoto, R.; Yokoyama, H.; Ogino, A.; Osada, T. Swine wastewater treatment technology to reduce nitrous oxide emission by using an aerobic bioreactor packed with carbon fibres. Anim. Prod. Sci. 2016, 56, 330-336. [CrossRef]

14. Osada, T.; Shiraishi, M.; Hasegawa, T.; Kawahara, H. Methane, nitrous oxide and ammonia generation in full-scale swine wastewater purification facilities. Front. Environ. Sci. Eng. 2017, 11, 10. [CrossRef]

15. Rice, E.W.; Bridgewater, L.; Association, A.P.H.; Association, A.W.W.; Federation, W.E. Standard Methods for the Examination of Water and Wastewater; American Public Health Association: Washington, DC, USA, 2012.

16. Kozich, J.J.; Westcott, S.L.; Baxter, N.T.; Highlander, S.K.; Schloss, P.D. Development of a Dual-Index Sequencing Strategy and Curation Pipeline for Analyzing Amplicon Sequence Data on the MiSeq Illumina Sequencing Platform. Appl. Environ. Microbiol. 2013, 79, 5112-5120. [CrossRef] [PubMed]

17. Caporaso, J.G.; Kuczynski, J.; Stombaugh, J.; Bittinger, K.; Bushman, F.D.; Costello, E.K.; Fierer, N.; Peña, A.G.; Goodrich, J.K.; Gordon, J.I.; et al. QIIME allows analysis of high-throughput community sequencing data. Nat. Methods 2010, 7, 335-336. [CrossRef] [PubMed]

18. Edgar, R.C. Search and clustering orders of magnitude faster than BLAST. Bioinformatics 2010, 26, $2460-2461$. [CrossRef]

19. IPCC. IPCC (Intergovernmental Panel on Climate Change), Climate Change 2013: The Physical Science Basis. Intergovernmental Panel on Climate Change, Stockholm; Cambridge University Press: Cambridge, UK, 2014.

20. Sabba, F.; Picioreanu, C.; Nerenberg, R. Mechanisms of nitrous oxide $\left(\mathrm{N}_{2} \mathrm{O}\right)$ formation and reduction in denitrifying biofilms. Biotechnol. Bioeng. 2017, 114, 2753-2761. [CrossRef] [PubMed]

21. Yamada, T.; Sekiguchi, Y.; Hanada, S.; Imachi, H.; Ohashi, A.; Harada, H.; Kamagata, Y. Anaerolinea thermolimosa sp. nov., Levilinea saccharolytica gen. nov., sp. nov. and Leptolinea tardivitalis gen. nov., sp. nov., novel filamentous anaerobes, and description of the new classes Anaerolineae classis nov. and Caldilineae classis nov. in the bacterial phylum Chloroflexi. Int. J. Syst. Evol. Microbiol. 2006, 56, 1331-1340.

22. Sekiguchi, Y.; Yamada, T.; Hanada, S.; Ohashi, A.; Harada, H.; Kamagata, Y. Anaerolinea thermophila gen. nov., sp. nov. and Caldilinea aerophila gen. nov., sp. nov., novel filamentous thermophiles that represent a previously uncultured lineage of the domain Bacteria at the subphylum level. Int. J. Syst. Evol. Microbiol. 2003, 53, 1843-1851. [CrossRef]

23. Kragelund, C.; Thomsen, T.R.; Mielczarek, A.T.; Nielsen, P.H. Eikelboom's morphotype 0803 in activated sludge belongs to the genus Caldilinea in the phylum Chloroflexi. FEMS Microbiol. Ecol. 2011, 76, 451-462. [CrossRef]

24. Eikelboom, D.H. Filamentous organisms observed in activated sludge. Water Res. 1975, 9, 365-388. [CrossRef]

25. Martins, A.M.P.; Pagilla, K.; Heijnen, J.J.; van Loosdrecht, M.C.M. Filamentous bulking sludge-A critical review. Water Res. 2004, 38, 793-817. [CrossRef] [PubMed]

26. Sanford, R.A.; Wagner, D.D.; Wu, Q.; Chee-Sanford, J.C.; Thomas, S.H.; Cruz-García, C.; Rodríguez, G.; Massol-Deyá, A.; Krishnani, K.K.; Ritalahti, K.M.; et al. Unexpected nondenitrifier nitrous oxide reductase gene diversity and abundance in soils. Proc. Natl. Acad. Sci. USA 2012, 109, 19709-19714. [CrossRef] [PubMed]

27. Wu, P.; Xiong, X.; Xu, Z.; Lu, C.; Cheng, H.; Lyu, X.; Zhang, J.; He, W.; Deng, W.; Lyu, Y.; et al. Bacterial Communities in the Rhizospheres of Three Mangrove Tree Species from Beilun Estuary, China. PLoS ONE 2016, 11, e0164082. [CrossRef]

28. Pereira, A.D.; Leal, C.D.; Dias, M.F.; Etchebehere, C.; Chernicharo, C.A.; de Araujo, J.C. Effect of phenol on the nitrogen removal performance and microbial community structure and composition of an anamox reactor. Bioresour. Technol. 2014, 166, 103-111. [CrossRef] [PubMed]

29. Zehr, J.P.; Ward, B.B. Nitrogen Cycling in the Ocean: New Perspectives on Processes and Paradigms. Appl. Environ. Microbiol. 2002, 68, 1015-1024. [CrossRef] [PubMed] 
30. Jetten, M.S.M.; Wagner, M.; Fuerst, J.; van Loosdrecht, M.; Kuenen, G.; Strous, M. Microbiology and application of the anaerobic ammonium oxidation ('anammox') process. Curr. Opin. Biotechnol. 2001, 12, 283-288. [CrossRef]

31. Lee, K.C.-Y.; Dunfield, P.F.; Morgan, X.C.; Crowe, M.A.; Houghton, K.M.; Vyssotski, M.; Ryan, J.L.J.; Lagutin, K.; McDonald, I.R.; Stott, M.B. Chthonomonas calidirosea gen. nov., sp. nov., an aerobic, pigmented, thermophilic micro-organism of a novel bacterial class, Chthonomonadetes classis nov., of the newly described phylum Armatimonadetes originally designated candidate division OP10. Int. J. Syst. Evol. Microbiol. 2011, 61, 2482-2490. [CrossRef]

32. McBride, M.J.; Liu, W.; Lu, X.; Zhu, Y.; Zhang, W. The Family Cytophagaceae. In The Prokaryotes: Other Major Lineages of Bacteria and the Archaea; Rosenberg, E., DeLong, E.F., Lory, S., Stackebrandt, E., Thompson, F., Eds.; Springer: Berlin/Heidelberg, Germany, 2014; pp. 577-593.

33. Kovaleva, O.L.; Merkel, A.Y.; Novikov, A.A.; Baslerov, R.V.; Toshchakov, S.V.; Bonch-Osmolovskaya, E.A. Tepidisphaera mucosa gen. nov., sp. nov., a moderately thermophilic member of the class Phycisphaerae in the phylum Planctomycetes, and proposal of a new family, Tepidisphaeraceae fam. nov., and a new order, Tepidisphaerales ord. nov. Int. J. Syst. Evol. Microbiol. 2015, 65 Pt 2, 549-555. [CrossRef]

34. Wunderlin, P.; Mohn, J.; Joss, A.; Emmenegger, L.; Siegrist, H. Mechanisms of $\mathrm{N}_{2} \mathrm{O}$ production in biological wastewater treatment under nitrifying and denitrifying conditions. Water Res. 2012, 46, 1027-1037. [CrossRef]

35. Zheng, H.; Hanaki, K.; Matsuo, T. Production of nitrous oxide gas during nitrification of wastewater. Water Sci. Technol. 1994, 30, 133-141. [CrossRef]

36. Tallec, G.; Garnier, J.; Billen, G.; Gousailles, M. Nitrous oxide emissions from secondary activated sludge in nitrifying conditions of urban wastewater treatment plants: Effect of oxygenation level. Water Res. 2006, 40, 2972-2980. [CrossRef]

37. Otte, S.; Grobben, N.G.; Robertson, L.A.; Jetten, M.S.; Kuenen, J.G. Nitrous oxide production by Alcaligenes faecalis under transient and dynamic aerobic and anaerobic conditions. Appl. Environ. Microbiol. 1996, 62, $2421-2426$.

38. Schulthess, R.V.; Gujer, W. Release of nitrous oxide $\left(\mathrm{N}_{2} \mathrm{O}\right)$ from denitrifying activated sludge: Verification and application of a mathematical model. Water Res. 1996, 30, 521-530. [CrossRef]

39. Hanaki, K.; Hong, Z.; Matsuo, T. Production of Nitrous Oxide Gas during Denitrification of Wastewater. Water Sci. Technol. 1992, 26, 1027-1036. [CrossRef]

40. Park, K.Y.; Inamori, Y.; Mizuochi, M.; Ahn, K.H. Emission and control of nitrous oxide from a biological wastewater treatment system with intermittent aeration. J. Biosci. Bioeng. 2000, 90, 247-252. [CrossRef]

41. Thörn, M.; Sörensson, F. Variation of nitrous oxide formation in the denitrification basin in a wastewater treatment plant with nitrogen removal. Water Res. 1996, 30, 1543-1547. [CrossRef] 